\title{
Initial basal cell carcinomas diagnosed in the National Campaign for Skin Cancer Prevention are smaller than those identified by the conventional medical referral system*
}

\author{
Thweicyka Pinheiro Wakiyama ${ }^{1}$ \\ Larissa Pierri Carvalho ${ }^{2}$ \\ Hélio Amante Miot $^{1}$
}

\author{
Maria Laura Marconi França ${ }^{2}$ \\ Mariangela Esther Alencar Marques ${ }^{3}$ \\ Juliano Vilaverde Schmitt ${ }^{1}$
}

DOI: http://dx.doi.org/10.1590/abd1806-4841.20175605

\begin{abstract}
BACKGROUND: Basal cell carcinoma is the malignant tumor most often diagnosed in the National Campaign for Skin Cancer Prevention (NCSCP). Little is known about the profile of these lesions compared to the profile of lesions diagnosed by conventional routes of public dermatological care.

Овјестіvе: To identify if basal cell carcinomas identified in prevention campaigns and referred to surgery are smaller than those routinely removed in a same medical institution.

Methods: Cross-sectional study including tumors routed from 2011-2014 campaigns and 84 anatomopathological reports of outpatients.

RESULts: The campaigns identified 223 individuals with suspicious lesions among 2,531 examinations (9\%), with 116 basal cell carcinomas removed. Anatomopathological examinations revealed that the primary lesions identified in the national campaigns were smaller than those referred to surgery by the conventional routes of public health care (28 [13-50] x 38 [20-113] $\mathrm{mm}^{2}, \mathrm{p}<0.01$ ). On the other hand, after a mean follow-up of $15.6 \pm 10.3$ months, $31 \%$ of cases identified in campaigns showed new basal cell carcinoma lesions.

STUDY LIMITATIONS: Retrospective study and inaccuracies in the measurements of the lesions. ConCLusions: The NCSCP promotes an earlier treatment of basal cell carcinomas compared to patients referred to surgery by the conventional routes of public health care, which can result in lower morbidity rates and better prognosis.
\end{abstract}

Keywords: Carcinoma, basal cell; Health promotion; Occupational health

\section{INTRODUCTION}

Non-melanoma skin cancer is the most common malignancy in humans and accounts for a significant part of health care spending as a whole. Although basal cell carcinoma (BCC) has low mortality rates, it corresponds to approximately $70 \%$ of cutaneous tumors, usually involving cosmetically sensitive areas. Despite its high frequency, strategies for skin cancer prevention are mainly limited to solar protection..$^{1-3}$

In order to clarify and publicize the importance of skin cancer primary preventive behavior, the Brazilian Society of Dermatology promotes annually since 1999 the National Campaign for Skin Cancer Prevention (NCSCP). Besides educational activities, the initiative carries out free dermatologic examination focused on the di- agnosis of skin cancers. Eight to $10 \%$ of examined individuals reveal a suspected malignant lesion, and $80 \%-90 \%$ of the cases are BCCs. ${ }^{1}$

However, because the data from these campaigns have not been systematically explored in the literature, it is not known whether these patients receive earlier treatment comparing to conventional medical referral system (CMRS). Moreover, little is known about the pattern of these BCC lesions, or about the risk these patients have of developing new lesions.

In this study, we compared pathological and demographic features of patients who underwent BCC surgeries referred by NCSCPs with those from CMRS in Public Basic Health Units.

\section{Received on 21.01.2016.}

Approved by the Advisory Board and accepted for publication on 06.02.2016.

* Work performed at Department of Dermatology - Faculdade de Medicina de Botucatu - Universidade Estadual Paulista "Júlio de Mesquita Filho" (UNESP) - Botucatu (SP), Brazil.

Financial support: None.

Conflict of interest: None.

1 Department of Dermatology and Radiotherapy - Faculdade de Medicina de Botucatu - Universidade Estadual Paulista "Júlio de Mesquita Filho" (FMBUNESP) (UNESP) - Botucatu (SP), Brazil.

Faculdade de Medicina de Botucatu - Universidade Estadual Paulista “Júlio de Mesquita Filho” (FMB-UNESP) (UNESP) - Botucatu (SP), Brazil.

3 Department of Pathology - Faculdade de Medicina de Botucatu - Universidade Estadual Paulista "Júlio de Mesquita Filho" (FMB-UNESP) - Botucatu (SP), Brazil. 
TABLE 1: Comparison between the characteristics of BCC lesions removed at our institution considering patients without history of prior skin cancer removal, according to their origin*

\begin{tabular}{llllll}
\hline Variable & NCSCP $(\mathbf{N}=\mathbf{7 3})$ & CMRS (N = 84) & P (biv.) & Odds ratio (IC 95\%)** & p (mult.)** \\
\hline Female & $46.6 \%$ & $47.6 \%$ & 0.90 & - & - \\
Age (years) & $69.3 \pm 13.4$ & $67.7 \pm 12.5$ & 0.24 & $1.02(0.99$ to 1.05$)$ & 0.21 \\
Location on the head or neck & $82.2 \%$ & $77.4 \%$ & 0.78 & - & - \\
Lesion area $\left(\mathrm{mm}^{2}\right) \#$ & $28[13-50]$ & $38[20-113]$ & $<0.01$ & $0.59(0.37-0.90)$ & 0.02 \\
Nodular histologic component & $89 \%$ & $90.5 \%$ & 0.80 & - & - \\
Sclerodermiform histological component & $5.5 \%$ & $10.7 \%$ & 0.26 & - & - \\
Superficial histological component & $6.9 \%$ & $2.4 \%$ & 0.25 & $2.51(0.47-13.52)$ & 0.29 \\
Constant & - & - & - & - & 0.30 \\
\hline
\end{tabular}

* BCC: Basal cell carcinoma. NCSCP: National Campaign for Skin Cancer Prevention between 2011 and 2014 (Botucatu/SP). CMRS: Conventional medical referral system (SUS) for patients living in Botucatu/SP. Used Student's t-test, Mann-Whitney, chi-square test or Fisher's exact test in the bivariate analyzes.

${ }^{* *}$ Conditional multiple logistic regression; $\mathrm{p}($ model $)=0.01 . ;{ }^{* * *}$ Means and standard deviations.; \# Medians [p25-p75]. Mm² in the multivariate analysis. Defined by $\pi \times$ width $\times$ length $/ 4$.

TABLE 2: Comparison of size $\left(\mathrm{mm}^{2}\right)$ of BCC removed lesions, according to sex and origin of the patient, considering only those without history of prior skin cancer surgery

\begin{tabular}{llll}
\hline & NCSCP* $^{*}$ & CMRS $^{*}$ & $\mathbf{p}^{* *}$ \\
\hline Female $(\mathrm{n}=74)$ & $27.5[13-50]$ & $33[20-64]$ & 0.09 \\
Male $(\mathrm{n}=83)$ & $28[13-79]$ & $50[28-113]$ & 0.03 \\
\hline
\end{tabular}

* BCC: Basal cell carcinoma. NCSCP National Campaign for Skin Cancer Prevention between 2011 and 2014 (Botucatu/SP). CMRS: Conventional medical referral system (SUS) for patients living in Botucatu/SP. Lesion Areas in square millimeters is defined by: $\pi \times$ width $\times$ length $/ 4$

** Mann-Whitney test.

\section{METHOD}

We conducted a cross-sectional study with a retrospective cohort component represented by the identification of tumor recurrence following patients referred to surgery by NCSCPs. The cases were represented by patients with initial BCC lesions coming from NCSCPs from 2011 to 2014, held in the city of Botucatu/SP. Surgical treatment of suspicious lesions was performed at Hospital de Clínicas da Faculdade de Medicina de Botucatu/UNESP - Botucatu/SP for a period of up to four months after diagnosis.

The control group consisted of 84 cases referred to surgery not by the NCSCPs, identified from 480 anatomopathological reports of BCC analyzed. The surgeries were performed between 2011 and 2014. The patients were residents of Botucatu/SP, without previous surgeries for skin cancer. Histological types were analyzed in a way that the same lesion could have one or more types among nodular/solid-cystic, sclerodermiform/infiltrative, and multicentric superficial components.

Areas of lesions $\left(\mathrm{mm}^{2}\right)$ were calculated based on the measures informed in the pathological reports by the formula: $\pi \mathrm{x}$ width $x$ length $/ 4$.

Continuous variables were expressed as mean \pm standard deviation, or median [p25-p75], depending on normality (Kolmogorov-Smirnov test). Categorical variables were expressed as percentages. Parametric and nonparametric bivariate tests were used (Student's t-test and Mann-Whitney) for continuous variables, and chi-square test or Fisher's exact test for categorical variables.

Tumor features were compared between new cases of BCC referred by the NCSCPs and by CMRSs in patients residents of Botucatu/SP through conditional logistic regression, including variables with $\mathrm{p}=<0.25$ in the bivariate analyzes. ${ }^{4}$
Associations in the multivariable analysis were represented by odds ratio and $95 \%$ confidence intervals. P values $<0.05$ were considered significant. Analyses were performed using the IBMSPSS 20 software. ${ }^{5}$

The study was approved by the Ethics Committee of the institution (CAAE: 40556215.6.0000.5411).

\section{RESULTS}

We identified 223 subjects with lesions suggestive of skin cancer out of 2,531 examinations (9\%) performed during the CNPCPs, mean age $68.5 \pm 13.9$ years, 105 (47\%) men and 118 (53\%) women. Of these, we found 144 patients $(65 \%)$ in our hospital records. 140 malignant lesions were confirmed, with 116 BCCs (83\%).

The 51 patients referred by the CNPCPs from 2011-2013 who treated BCCs in our institution were followed for an average of $15.6 \pm 10.3$ months; $16(31.4 \%)$ had new tumors, particularly those with previous BCC diagnostics $(63.6 \%$ vs. $22.5 \%$, OR $=6.03$ (1.44 to 25.32); $\mathrm{p}=0.02$ ).

Among the new cases of excised BCCs referred by the NCSCP, $86 \%$ had less than $1 \mathrm{~cm}$ in diameter, which occurred in only $71 \%$ of new cases referred by CRPs (OR $=2.52$ (1.11 to 5.71$), \mathrm{p}=$ 0.02).

Table 1 compares the new cases of BCC identified in NCSCPs to CMRS cases of patients residents in Botucatu/SP. Results show the removal of smaller tumor in NCSCP cases, regardless of histological type, location, or demographic variables.

Table 2 and graph 1 illustrate, for each sex, tumor size in ac-cordance with routing paths, emphasizing a higher male tendency to larger tumors in CMRS cases.

\section{DISCUSSION}

The present study identified no differences in demographic patterns, location, and histological type of BCCs from NCSCPs in relation to routing paths. On the other hand, pathological examination revealed that tumors identified by the NCSCPs were smaller, suggesting an earlier treatment.

A study conducted by Eide and colleagues (2005) found factors related to the surgical defect size after the removal of keratinocytic tumors by micrographic surgery. They identified the interference of the time interval between diagnosis and treatment in 


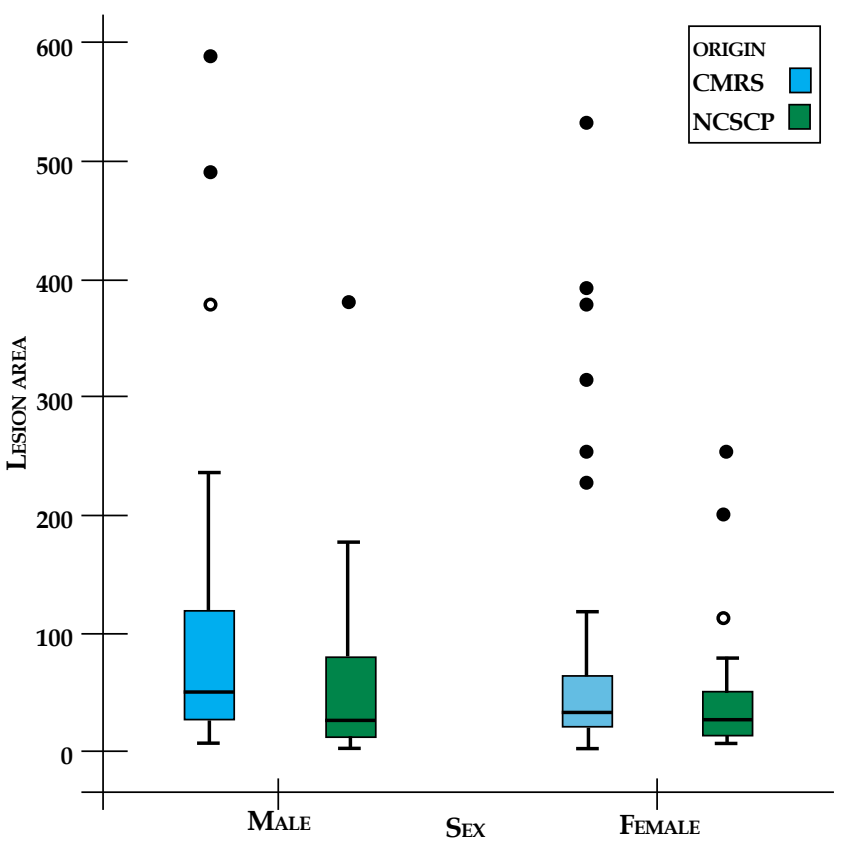

* BCC: Basal cell carcinoma. NCSCP National Campaign for Skin Cancer Prevention between 2011 and 2014 (Botucatu/SP). CMRS: Conventional medical referral system (SUS) for patients living in Botucatu/SP. Lesion area is in square millimeters and defined by: $\pi$ $x$ width $x$ length $/ 4$.

GraPH 1: Boxplot of the size of the BCC lesions removed $\left(\mathrm{mm}^{2}\right)$ according to sex and origin of the patient, considering only those without history of prior skin cancer surgery

the final size of the surgical wound. After an interval longer than one year, the wound doubled in size. Likewise, they found that the defects were smaller when the initial evaluation was made by a dermatologist. ${ }^{6}$

NCSCPs combine two factors identified by Eide (2005) that favor early treatments: patient assessment by a dermatologist and greater flexibility in scheduling the surgery. Kirkup et al. (1999) found an average increase of $4.7 \mathrm{~mm}^{2}(0.5 \mathrm{~mm}$ in diameter) in the size of BCCs on the face in a 10-week period. In our study, the median difference in tumor size was $10 \mathrm{~mm}^{2}(1 \mathrm{~mm}$ in diameter) between NCSCPs and CMRSs, which, in a speculative interpretation, might suggest something about 20 weeks of precocity in the treatment of tumors diagnosed by the NCSCPs. ${ }^{7}$

The monitoring of treated patients showed frequent recurrence of cutaneous neoplasias, especially when the patient had a personal history of skin cancer prior to the NCSCP, reinforcing the need for clinical follow-up. A systematic review performed in 2000 identified a cumulative risk of $44 \%$ for development of a new BCC in an average period of 3 years, corresponding to 10 times the expected for the general population. ${ }^{8,9}$

The NCSCP seems to impact mainly in men in relation to early diagnosis, illustrating that men referred by the CMRSs tend to have more advanced neoplasias. Some behavioral and cultural features related to gender and health care were reported. In addition to men being probably more exposed to the main environmental risk factors for skin cancers, they tend to delay medical evaluation. Campaigns that focus on this risk group can achieve a greater reduction of skin cancer morbidity. ${ }^{6,10-13}$

Despite the limitations related to retrospective studies, to possible inaccuracies in the measurements of the lesions, and to selection biases, our results are consistent with the literature. However, they are unprecedented by identifying the precocity in the treatment of tumors diagnosed in CNPCPs. They also reinforce the role of campaigns in clarifying the population about the disease, which would help reduce public health care costs by the promotion of primary and secondary prevention.

Finally, we would like to highlight that campaigns with greater capillarity in cities, in an itinerant way, and targeted to highrisk patients (elderly, with family or personal history, light-skinned, and chronically exposed to the sun) would optimize the results found in this study.

\section{CONCLUSION}

The NCSCP has promoted earlier treatment of basal cell carcinomas compared to patients referred to surgery by the conventional routes of public health care, which can result in lower morbidity and better prognosis. 


\section{REFERENCES}

1. Sociedade Brasileira de Dermatologia. Análise de dados das campanhas de prevenção ao câncer da pele promovidas pela Sociedade Brasileira de Dermatologia de 1999 a 2005. An Bras Dermatol. 2006;81:533-9.

2. Schmitt JV, Chinem VP, Marques MEA, Miot HA. Aumento da incidência de carcinoma basocelular em hospital universitário: 1999 a 2009. An Bras Dermatol 2011;86:375-7.

3. Souza CFD, Thomé EP, Menegotto PF, Schmitt JV, Shibue JRT, Tarlé RG. Topografia do carcinoma basocelular e suas correlações com o gênero, a idade e o padrão histológico: um estudo retrospectivo de 1.042 lesões. An Bras Dermatol. 2011;86:272-7.

4. Wakkee M, Hollestein LM, Nijsten T. Multivariable analysis. J Invest Dermatol. 2014;134:e2

5. Ibm.com [Internet]. SPSS software. Armonk: IBM Corporation; 2015. [cited 2015 Dec 01]. Available from: http://www.ibm.com/analytics/us/en/technology/ spss/spss.html

6. Eide MJ, Weinstock MA, Dufresne RG Jr, Neelagaru S, Risica P, Burkholder GJ, et al. Relationship of treatment delay with surgical defect size from keratinocyte carcinoma (basal cell carcinoma and squamous cell carcinoma of the skin). J Invest Dermatol. 2005;124:308-14.

7. Kirkup ME, De Berker DA. Clinical measurement of dimensions of basal cell carcinoma: effect of waiting for elective surgery. Br J Dermatol. 1999;141:876-9.

8. Ocanha JP, Dias JT, Miot HA, Stolf HO, Marques ME, Abbade LP. Relapses and recurrences of basal cell face carcinomas. An Bras Dermatol. 2011;86:386-8.

9. Marcil I, Stern RS. Risk of developing a subsequent nonmelanoma skin cancer in patients with a history of nonmelanoma skin cancer: a critical review of the literature and meta-analysis. Arch Dermatol. 2000;136:1524-30.

10. Wyke S, Hunt K, Ford G. Gender differences in consulting a general practitioner for common symptoms of minor illness. Soc Sci Med. 1998;46:901-6.

11. Smith LK, Pope C, Botha JL. Patients' help-seeking experiences and delay in cancer presentation: a qualitative synthesis. Lancet. 2005;366:825-31.

12. Gomes R, Nascimento EF, Araújo FC. Por que os homens buscam menos os serviços de saúde do que as mulheres? As explicações de homens com baixa escolaridade e homens com ensino superior. Cad Saude Publica. 2007;23:56574.

13. Machin R, Couto MT, Silva GS, Schraiber LB, Gomes R, Santos Figueiredo Wd, et al. Concepções de gênero, masculinidade e cuidados em saúde: estudo com profissionais de saúde da atenção primária. Cien Saude Colet 2011;16:4503-12.

\author{
MAILING ADDRESS: \\ Juliano Vilaverde Schmitt \\ Departamento de Dermatologia, s/n \\ Campus da Unesp \\ 18618-000 Botucatu, SP \\ Brazil \\ E-mail:julivs@gmail.com
}

How to cite this article: Wakiyama TP, França MLM, Carvalho LP, Marques MEA, Miot HA, Schmitt JV. Initial basal cell carcinomas diagnosed in the National Campaign for Skin Cancer Prevention are smaller than those identified by the conventional medical referral system. An Bras Dermatol. 2017;92(1):26-9. 